\title{
Casualization of Labour: Implications of the Triangular Employment Relationship in Nigeria
}

\author{
Gogo George Otuturu \\ Faculty of Law, Niger Delta University, Wilberforce Island, Nigeria \\ Email: otuturulaw@gmail.cocm
}

How to cite this paper: Otuturu, G. G. (2021). Casualization of Labour: Implications of the Triangular Employment Relationship in Nigeria. Beijing Law Review, 12, 677-690.

https://doi.org/10.4236/blr.2021.122036

Received: October 20, 2020

Accepted: June 26, 2021

Published: June 29, 2021

Copyright $\odot 2021$ by author(s) and Scientific Research Publishing Inc. This work is licensed under the Creative Commons Attribution International License (CC BY 4.0).

http://creativecommons.org/licenses/by/4.0/

(c) (i) Open Access

\begin{abstract}
Casualization is a global phenomenon. It is a form of nonstandard work arrangements practized in both developed and developing countries with varying degrees of regulation. Employers see it as a means of cutting costs and achieving flexibility, while workers see it as a work arrangement that denies them the right to employment benefits and to unionize and bargain collectively. This paper examines the concept of casualization and the implications of the triangular employment relationship in Nigeria in the context of international labour standards. It also examines the rights of casual workers to employment benefits and trade union rights in Ghana and China. It argues that the triangular or disguised employment relationship, which is the commonest form of casual employment in the banking and oil and gas sectors in Nigeria, fall outside the purview of the Labour Act. Amongst other things, the paper finds that the triangular or disguised employment relationship does not yield itself to the rights and benefits provided for workers in the traditional employment relationship and that it has segmented the labour market into core, non-core and peripheral zones. The paper calls for a comprehensive review of the Labour Act in line with international labour standards. It recommends the Ghana model with the necessary changes to suit local circumstances.
\end{abstract}

\section{Keywords}

Casualization, Flexibility, Globalization, Outsourcing, Subcontracting

\section{Introduction}

Casualization is a form of nonstandard work arrangements practiced globally. In the international literature, nonstandard work arrangements cover all forms of temporary employment outside the traditional model of permanent and conti- 
nuous employment with an employer. The term is used interchangeably with contingent, atypical, flexible and alternative work arrangements (Fourie, 2008) and includes temporary work, part-time work, subcontracting, outsourcing, labour hire, zero-hour employment, dependent self-employment and disguised employment relationships (ILO, 2016).

Casualization is not a new concept. It has been in use for many decades. What is new, however, is the utilization of workers on nonstandard work arrangements to avoid standard employment relationships (Bodibe, 2006). With globalization, trade liberalization and technological innovation, coupled with unemployment and poverty, casualization has become a more widespread feature of contemporary labour markets. Because of unemployment and poverty, people are ready to accept work under any kind of arrangements.

Traditionally, the term "casuals" or "casual workers" was used to refer to workers who are employed in irregular and seasonal employment with intermittent breaks, but it has come to refer to all forms of non-standard workers (Sydney University, Seminar Paper, 2012)1. Thus, casualization may be defined simply as the utilization of workers on nonstandard work arrangements in place of fulltime permanent employment. It can also be defined as the practice whereby employers engage casual workers rather than full time permanent workers.

The International Labour Organization defines "casuals" as "workers who have an explicit or implicit contract of employment which is not expected to continue for more than a short period, whose duration is to be determined by national circumstances" (ILO, 2017) ${ }^{2}$. This definition has been criticized for being ambiguous as it did not address the rights of the workers in this category and what constitutes a short duration (Animashaun, 2007). The determination of these issues by reference to national circumstances is largely responsible for the variations in national laws for the duration of causal work and the rights of casual workers.

In the past, casual workers were engaged to supplement full time workers during peak business periods, particularly in agriculture, construction, manufacturing and retail business. It is akin to the "Just in Time" business strategy introduced by the US manufacturer, Henry Ford. This business strategy entails producing goods in response to demand rather than in anticipation of demand. It challenges the idea of maintaining a permanent workforce in idle times. It poses the question, "Why not bring in labour and skills as required, and save the organization the costs associated with maintaining a permanent workforce?"

\footnotetext{
${ }^{1}$ In Australia, casual jobs are commonly understood as jobs that attract an hourly rate of pay but very few of the other rights and benefits, such as the right to notice, the right to severance pay and most forms of paid leave (annual leave, public holidays, sick leave, etc.), that are normally associated with "permanent" jobs. See May et al. (2012), "The Rise and Rise of Casual Work in Australia-Who Loses?” (Sydney University, Seminar Paper 2012).

${ }^{2}$ ILO, Resolution Concerning International Classification of Status in Employment adopted by the International Conference of Labour Statisticians, January 1993, paragraph 14 (e) http://www.stats.oecd.org/glossary/detail.asp?ID=293 accessed 12 March 2017; see also ILO, Nonstandard Employment Around the World: Challenges, Shaping Prospects (ILO 2016) 22 where the ILO defines "casual work" slightly differently as "work that is executed for a very short period, or occasionally and intermittently, often for a specific number of hours, days or weeks".
} 
(Palmer-Brown, 2017).

In the past also, casual employment was mainly for unskilled workers. Nowadays, however, the business model in many industries is such that casual workers are an integral part of a permanent workforce and not just a supplement to a permanent workforce in peak business periods. Both skilled and unskilled workers are engaged as casual workers in place of permanent workers. In fact, one retail outlet uses the phrase "permanent casuals" to describe their casual workers, indicating that they often work for years for a specific outlet ${ }^{3}$.

The ultimate outcome of casualization is reduction in the number of permanent workers and increase in the number of non-permanent workers (Fenwick et al., 2007). This helps the employers to move towards arrangements that reduce the costs and risks associated with the standard employment relationship through using cheaper labour, reduced wages and employment benefits and increased flexibility. There are three kinds of flexibility. These are employment flexibility (the freedom to change employment levels quickly and cheaply), wage flexibility (the freedom to determine wage levels without restraint) and functional flexibility (the freedom to altar work processes, terms and conditions of employment, etc, quickly and cheaply) (Cheadle, 2006).

This paper examines the law and practice of casualization and the implications of the triangular employment relationship in Nigeria. It also examines international labour standards and the rights of casual workers to employment benefits and trade union rights in Ghana and China. It argues that the triangular and disguised employment relationships, which are the commonest forms of casual employment in the banking and oil and gas sectors in Nigeria, fall outside the purview of the Labour Act. The paper recommends an urgent review of the Labour Act in line with international labour standards especially as the Labour Act has become quite obsolete.

\section{Triangular Employment Relationship}

In developed countries, there is a readjustment of the legal framework for the regulation of casual workers in such a way that casual workers can enjoy employment benefits and the right to unionize and bargain collectively (Danesi, 2017). In developing countries, on the other hand, especially in Nigeria, there is virtually no legal framework for the regulation of casual workers. This has created loopholes for employers to move towards the triangular or disguised employment relationship which is the commonest form of casualization practized in most countries.

In Nigeria, casualization is used generally to describe work arrangements that are characterized by job insecurity, low wages and lack of employment rights such as pension, gratuity and severance payments that accrue to full-time permanent workers (Eyongndi, 2016; Fapohunda, 2012; Danesi, 2021). There are three categories of casual workers in the Nigerian labour market. These are:

${ }^{3}$ Fourie (n1) 113. 
1) Workers who are employed directly by a firm on casual, seasonal, fixedterm or temporary basis;

2) Workers who are employed in a triangular employment relationship such as outsourcing and subcontracting arrangements;

3) Workers who are employed in a disguised employment relationship such as independent contractors and home based workers.

The traditional employment relationship normally involves two parties: the employer and the employee. But the triangular employment relationship and disguised employment relationship present a more complex situation in which one or more third parties are involved. It occurs when the employees of an enterprise (the "service provider") perform work for a third party (the "user enterprise") to whom their employer provides labour or services. From a legal standpoint, this kind of employment relationship presents some difficulty as the employees concerned may find themselves interacting with two or more intermediaries, each of whom assume certain functions of a traditional employer (ILO, 2003).

This is the commonest form of casualization practized in the banking and oil and gas sectors in Nigeria. The client company (the "user enterprise") procures the services of a labour contractor (the "service provider") who recruits the workers and supplies them to the client company. The service provider remains the employer and the workers are referred to as "contract staff" or "contract workers" in preference to "casual workers." The labour contractor retains the right to withdraw such workers and recycle them amongst various client companies. The purpose of this triangular arrangement is to relieve the client company of the responsibilities and the costs associated with being the employer of the workers (Atilola, 2014).

In the landmark case of PENGASSAN v Mobil Producing Nigeria Unlimited (2013) the respondent engaged Manpower Services (MPS) Contractors, under which category is the appellant's employers, to provide various services in the course of normal business. These classes of workers are typically auxiliary support service workers, whose employment and disengagement, as the case may be, are not directly negotiated with the respondent, but with the MPS Contractors who employ such workers under their specific contract of employment. These contract workers are unionized and negotiate their terms and conditions of service with their employers, the MPS Contractors. Sometime in January 2006, against laid down rules and regulations, especially in breach of contracts of engagement between the contract workers and their employers, the appellant's contract workers began to agitate for "Equal Pay for Equal Work" with the respondent's regular workers and sought to directly negotiate their grievances with the respondent. This led to the breakdown of law and order which compelled the respondent to invoke the relevant clause in its agreement with the MPS Contractors urging the latter to withdraw their affected workers from the respondent's premises.

It was against these facts that the appellant filed its memorandum before the 
Industrial Arbitration Panel seeking for an order to reinstate the contract workers whose services were disengaged by their employers. The Industrial Arbitration Panel found that there is no contract between the respondent and members of the appellant. The National Industrial Court dismissed the appeal and stated that the relationship between the parties yields to a triangular employment relationship which comes in a variety of forms the best known of which (and which relates to the instant appeal) is the use of contractors and private employment agencies. Justice Kanyip said:

The ILO does not brand as invalid or unlawful or as wrong the triangular employment relationship; neither had it even branded the practice of outsourcing or contracting out as an unfair labour practice as the appellant made it out in some of its communications with the Ministry of Labour regarding this matter. All the ILO enjoins is that the respective laws of member States on the issue should be respected and applied ${ }^{4}$.

It is to be emphasized that legislations that protect the rights of workers are based on the traditional employment relationship. Workers in triangular and disguised employment relationships do not fall within the purview of the protection and rights available to permanent workers (Danesi, 2017). This is clear from the definition of "worker" under the Labour Act. (2004) Under the Act, "worker" means-

... any person who has entered into or works under a contract with an employer, whether the contract is for manual or clerical work or is expressed or implied or oral or written, and whether it is a contract of service or a contract personally to execute any work or labour... ${ }^{5}$

It is obvious that the definition of worker is based on the traditional employment relationship between an employer and an employee. However, the definition distinguishes between a contract of service and a contract for services. Under a contract of service, an employer engages an employee who works or provides services in a situation of subordination to or dependency on the employer; or is integrated in the employer's organization; or does not assume the risks specific to an employer ${ }^{6}$. Under a contract for service, an employer engages a selfemployed person or an independent contractor to execute any work or labour directly for the employer.

What this means is that the Labour Act applies to only the traditional employment relationship between an employer and an employee. It does not apply to the triangular or disguised employment relationship. The most visible effect of this type of employment relationship is that the worker does not obtain the benefits provided to employees in labour legislations and collective agreements. In fact, the ILO Committee of Experts on the Application of Conventions and 
Recommendations has noted that the current trend by employers to move towards replacing the traditional employment contract with other types of contract is to evade the protection provided under the Termination of Employment Convention $1982^{7}$.

However, under the Employees' Compensation Act 2010 the definition of employee has been extended to persons employed on casual basis. Thus, any worker under dependent labour relationship who suffers any of the injuries, disability or occupational diseases can claim under the Act (Worugji, 2013). It is submitted that "employment" in this context envisages the relationship between the worker and the service provider ${ }^{8}$.

In the case of Abel v Trevi Foundation Nigeria Ltd (2014) where the claimant who was employed by the defendant as a "contract staff" sustained injuries in the course of his employment, the National Industrial Court relied on the definition of "employee" under the Employees' Compensation Act 2010 and held that the claimant is an employee of the defendant and therefore entitled to compensation for injuries sustained in the course of his employment with the defendant. The Court stated that the definition of who is an employee has been extended widely by the Act to include persons engaged on temporary or casual basis.

The Trade Unions Act (2004) also extends the definition of "worker" for the purpose of forming or joining a trade union to include a temporary worker. The Act defines a trade union as "any combination of workers, whether temporary or permanent, the purpose of which is to regulate the terms and conditions of employment of workers". It is submitted that "temporary worker" is broader term than "casual worker" and includes a casual or contract worker. Thus, a worker, for the purpose of forming and joining a trade union in Nigeria, includes a person engaged on temporary or casual basis.

In Patovilki Industrial Planners Ltd v National Union of Hotels and Personal Services Workers (1978-2006) the appellant company was into the business of industrial cleaning. The respondent union sought to unionize the appellant's workers but the company refused on the basis that they were casual workers. The respondent union therefore declared a trade dispute which was heard by the Industrial Arbitration Panel, which gave an award in favour of the respondent union. On appeal, the National Industrial Court upheld the award of the IAP that both permanent and casual workers have the right to form a trade union. The Court stated that section 1 (1) of the Trade Unions Act allows workers, whether permanent or temporary, to form a trade union and a relevant trade union can unionize workers who are employed on casual basis.

In most organizations, however, casual workers are denied the right to form or join trade unions and to bargain collectively with their employers. In practice, once employed, the casual or contract worker is made to sign a yellow dog contract, (Okafor, 2007) that is, employment of a worker subject to the condition that he 
shall not join a union or shall relinquish trade union membership (Otuturu, 2009).

It is submitted that this practice is a violation of the constitutional and statutory right of every worker to form or join a trade union of his choice for the protection of his economic and other interests. This right is enshrined in the Constitution of the Federal Republic of Nigeria 1999, as amended, which guarantees every citizen the right to assemble freely and to form or join a trade union of his choice for the protection of his interests. The constitutional provision on freedom of association is reinforced by the Labour Act 2004, which provides that "No contract shall make it a condition of employment that a worker shall or shall not join a trade union or shall or shall not relinquish membership of a trade union..."

It is submitted that by virtue of section 40 of the Constitution of the Federal Republic of Nigeria 1999 (as amended) and section 9 (6) (a) of the Labour Act 2004, all yellow dog contracts by which employers seek to deny the rights of casual workers to join trade unions and to bargain collectively for better wages and other conditions of employment are illegal and of no effect in Nigeria.

It is noteworthy that the Minister of Labour (2004) has issued Guidelines on Contract Staffing/Outsourcing in the Oil and Gas Sector. Under the Guidelines, all jobs on the organogram of a company operating in the oil and gas industry must be occupied by permanent employees and outsourcing shall be restricted to non-core business of the company except for proven short term projects. The Guidelines also enjoin employers of contract staff to enter into collective agreements with the contract staff. The Guidelines further empower the principal oil company to terminate the labour outsourcing contracts where the labour contractors fail to comply with extant labour laws. However, the Guidelines have not been be applied by the National Industrial Court and no principal oil company has invoked its coercive powers to revoke any labour contract.

\section{International Labour Standards}

The protection of "contract labour" was extensively discussed at the International Labour Conference in 1997-98 leading to the adoption of the Private Employment Agencies Convention 1997 ${ }^{10}$. The Convention highlights in its Preamble the role that private employment agencies may play in a well-functioning labour market, while recalling the need to protect workers. The Convention is applicable to all private employment agencies, all categories of workers and all branches of economic activity except seafarers ${ }^{11}$ and enjoins member States to take measures to ensure that workers recruited by private employment agencies are not denied the right to freedom of association and the right to collective bargaining ${ }^{12}$ and that the agencies treat workers without discrimination ${ }^{13}$.

ILO Convention 181 is supplemented by the Private Employment Agencies

\footnotetext{
${ }^{10}$ ILO Convention No. 181.

${ }^{11}$ Ibid, article 2.

${ }^{12}$ Ibid, article 4.

${ }^{13} \mathrm{Ibid}$, article 5 .
} 
Recommendation, $1997^{14}$ which provides, inter alia, that workers employed by private employment agencies and made available to user enterprises should, where appropriate, have a written contract of employment specifying their terms and conditions of employment, with information on such terms and conditions provided at least before the effective beginning of their assignment ${ }^{15}$ and that private employment agencies should also not make workers available to a user enterprise to replace workers of that enterprise who are on strike ${ }^{16}$.

Other ILO Conventions and Recommendations of particular relevance to workers in nonstandard work arrangements include the Equal Remuneration Convention, $1951^{17}$, the Discrimination (Employment and Occupation) Convention, $1958^{18}$, the Employment Policy Convention, $1964^{19}$, the Part-Time Work Convention, 1994 ${ }^{20}$, and the Employment Relationship Recommendation $2006^{21}$.

The Equal Remuneration Convention, 1951 is aimed at eliminating discrimination between men and women with regard to remuneration by ensuring the application to all workers of the principle of equal remuneration for men and women for work of equal value ${ }^{22}$. The Discrimination (Employment and Occupation) Convention, 1958 enjoins member States to undertake and pursue a national policy designed to promote equality of opportunity and treatment in respect of employment and occupation, with a view to eliminating any discrimination on grounds of race, colour, sex, religion, political opinion, national extraction or social origin and any other form of discrimination as may be so prescribed, nationally, which has the effect of nullifying or impairing equality of opportunity in employment or occupation ${ }^{23}$.

The Part-Time Work Convention, 1994 aims at ensuring that part-time workers get the same wages (pro rata), social security schemes, occupational health and safety protection, maternity protection, trade union rights, paid annual and public holidays and sick leave as full-time workers, It is supplemented by the Part-Time Work Recommendation, $1994^{24}$ which enjoins employers to provide information to part-time workers on their specific conditions of employment. The Employment Relationship Recommendation 2006 enjoins members States to formulate a national policy to guarantee effective protection for workers in an employment relationship ${ }^{25}$.

In the African region, the African Charter on Human and Peoples' Rights (1981) provides that every individual shall have the right to work under suitable

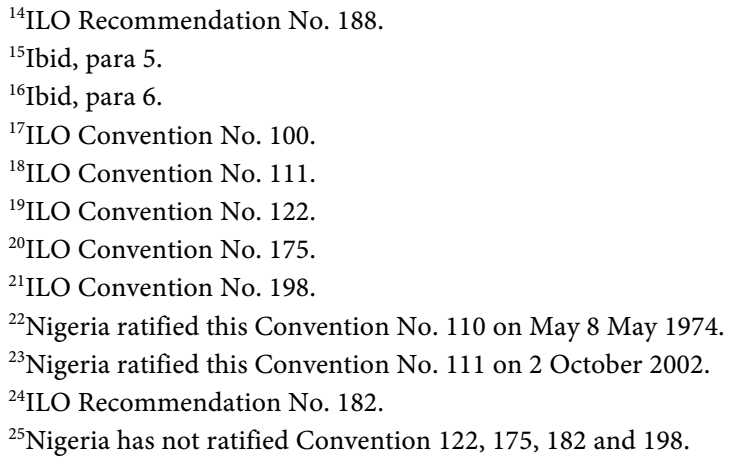


and satisfactory conditions and shall receive equal pay for equal work. This implies that there should not be any form of discrimination in employment between workers in standard employment and workers in non-standard work arrangements (Rasak, 2011). The Charter is part of Nigerian domestic law by virtue of the African Charter on Human and Peoples' Rights (Ratification and Enforcement) Act 2004.

\section{The Position in Other Jurisdictions}

In some jurisdictions, legislations have been enacted to regulate various aspects of casualization. A good example is Ghana. The Ghanaian Labour Act 2003 was drafted with the assistance of the International Labour Organization. It is, therefore, in substantial compliance with international labour standards.

Under the Labour Act 2003 a "worker" is defined as a person employed under a contract of employment whether on a continuous, part-time, temporary or casual basis. A "casual worker" is defined as a worker engaged on a work which is seasonal or intermittent and not for a continuous period of more than six months and whose remuneration is calculated on a daily basis, while a "temporary worker" is defined as a worker who is employed for a continuous period of not less than one month and is not a permanent worker or employed for a work that is seasonal in character ${ }^{26}$.

Although the contract of employment of casual worker need not be in writing, the Act stipulates the rights of casual worker. In particular, a casual worker is entitled to equal pay for work of equal value, have access to any medical facility made available for workers generally by the employer, be entitled to be paid for overtime work and be paid full remuneration for each day on which he attends work $^{27}$.

The Act provides for a transition of a worker from temporary to permanent work. It provides that a temporary worker who is employed by the same employer for a continuous period of six months and more shall be treated as a permanent worker ${ }^{28}$. In addition, an employer has a statutory obligation to pay each temporary or casual worker full remuneration in respect of every public holiday ${ }^{29}$.

China has also taken some drastic measures to regulate casual or contract employment in line with international labour standards. Under the Labour Contract Law 2008, casual or dispatched workers, as they are called in China, are recruited by labour dispatch firms and hired to user firms under fixed term contracts of not less than two years $(\mathrm{Xu}, 2012)$. The labour dispatch firm remains the employer of the dispatched worker and pays the worker the remuneration due to him or her. The dispatched worker is entitled to be paid overtime, performance bonuses and benefits relevant to the post irrespective of employment

\footnotetext{
${ }^{26}$ Ibid, s. 78 .

${ }^{27}$ Ibid, s. 74 .

${ }^{28}$ Ibid, s. 75(1).

${ }^{29}$ Ibid, s. 77(1).
} 
status and is entitled to earn the same pay as that received by the regular workers of the user firm. The dispatched workers also have the right to form or join a labour union while in employment to safeguard their lawful rights and interests.

The Labour Contract Law 2008 was amended in 2012 which came into force in 2013. The amendments were set out to limit the overuse of agency work. The amendments emphasized that the primary form of employment is engagement of staff through employment contracts with the ultimate employer rather than through labour dispatch arrangements. The amendments also provide that the number of workers who are engaged through labour dispatch company cannot exceed a certain percentage of the total workforce, details of which are to be provided by the Ministry of Human Resources and Social Security in a separate regulation (ILO 2014).

As at March 2016, following a two-year window for companies to adjust, the new regulations require that dispatched workers shall not exceed 10 percent of the total number of employees at a given company. In addition, employers are not allowed to engage workers in core business positions without the benefit of a long-term employment. The regulations require employers to engage workers through dispatch companies for temporary, ancillary and substitute positions only.

A "temporary" work position refers to a job that lasts not longer than six months. An "ancillary" position refers to a position providing supporting services to the core business positions of an enterprise, such as security and canteen services. A "substitute" position refers to a position in which the staff engaged through a labour dispatch company temporarily replaces an existing employee on study leave, maternity leave, sick leave or some other reason (Fair Labour Association, 2016).

\section{Findings and Analysis}

The triangular or distinguished employment relationship does not yield itself to the rights and benefits provided for workers under the traditional employment relationship. Thus, the rights and benefits provided for workers under the Labour Act 2004 are not available to workers under the triangular and disguised employment relationship. As one writer puts it, workers involved in casual jobs suffer a substantial deficit in their rights and benefits compared with employees in standard or permanent jobs (Kalejaiye, 2014). Such rights and benefits include statutory notice periods, pension and gratuity, security of employment and redundancy payments (May, 2012).

The above finding is consistent with the views expressed by the ILO Committee of Experts on the Application of Conventions and Recommendations. In its $91^{\text {st }}$ Session, the Committee stated that the current trend by employers to move towards replacing the traditional employment contract with other types of contract is to evade the protection provided under the Termination of Employment Convention $1982^{30}$. 
The triangular or disguised employment relationship does not also yield itself to any meaningful collective bargaining. The main reason workers form or join trade unions is for the protection of their economic and other interests. This is achieved largely through collective bargaining. The union represents the workers to bargain collectively with their employer for better wages and other conditions of employment.

It is clear from the case of PENGASSAN $v$ Mobil Producing Nigeria Unlimited $^{\beta 1}$ that the casual or contract workers in MPNU earned lower wages than the regular workers in MPNU. They have the same qualifications and skills and they do the same jobs as the regular workers in MPNU, but they are paid lower wages. It is this disparity in wages that informed the members of PENGASSAN (Contract Staff Branch) to agitate for "Equal Pay for Equal Work" and to seek to bargain directly with MPNU, but they were resisted because they had no contractual relationship with MPNU.

While collective bargaining is notionally possible between the members of PENSGASSAN (Contract Staff Branch) and the MPS Contractors, the nature and form of employment militates against it. This is because the terms of the contract between the members of PENGASSAN (Contract Staff Branch) and the MPS Contractors are largely determined by the contract between the MPS Contractors and MPNU. This is the plight of casual or contract workers in Nigeria.

The triangular or disguised employment relationship has further segmented the labour market into core zone, non-core zone and peripheral zone. The core zone is made up of workers who are engaged on full-time regular employment in the formal sector. The non-core zone is made up of workers who are engaged on casual, atypical and other forms of nonstandard work arrangements still in the formal sector. The periphery is made up of workers who are self-employed in the informal sector ${ }^{32}$. This segmentation is consistent with the Guidelines on Contract Staffing/Outsourcing in the Oil and Gas Sector, which restrict outsourcing in the oil and gas sector to non-core business of the company except for proven short term projects.

\section{Conclusion and Suggestions for Reform}

Nigeria is a leading member of the African Union as well as a member of the Governing Body of the International Labour Organization. This dual role places her in a position of responsibility to lead by example. In particular, the Federal Government of Nigeria must make deliberate efforts to ensure that the country's labour laws are in tandem with international labour standards.

At present, there is no general legal framework for the regulation of casual or contract workers and other forms of nonstandard work arrangements in Nigeria. The Guidelines on Contract Staffing/Outsourcing in the Oil and Gas Sector, as the name implies, are restricted to the oil and gas industry. Besides, the Guide-

${ }^{30} \mathrm{ILO}(\mathrm{n} 13) 26$.

${ }^{31}$ MPNU (n15).

${ }^{32}$ Bodibe (n4) 56. 
lines have not been applied by the National Industrial Court and no oil company has invoked its coercive power to revoke any labour contract for noncompliance with them.

The definition of "worker" under the Labour Act is too narrow and does not contemplate new forms of employment relationship especially the triangular or disguised employment relationship. With the opening up of the Nigerian economy to attract direct foreign investment especially in the power, rail transport, manufacturing and offshore oil and gas sectors, the traditional model of employment is steadily giving way to new forms of employment.

In the light of the observed pitfalls in the laws relating to casualization in $\mathrm{Ni}$ geria, there is an urgent need for a comprehensive review of the Labour Act in line with international labour standards as the Labour Act has become quite obsolete $^{33}$. In this regard, the Ghana model is recommended. The choice of Ghana is significant for two reasons. First of all, Ghana is located in West Africa like Nigeria. Secondly, Ghana is a developing country like Nigeria. The provisions of the Ghanaian Labour Act No. 651 of 2003 can, therefore, be easily adapted to national circumstances in Nigeria.

\section{Conflicts of Interest}

The author declares no conflicts of interest regarding the publication of this paper.

\section{References}

Abel v Trevi Foundation Nigeria Ltd (2014). DJNIC 288-289.

African Charter on Human and Peoples' Rights (Ratification and Enforcement) Act, Cap A9, Laws of the Federation of Nigeria, 2004.

African Charter on Human and Peoples' Rights 1981, Article 15.

Animashaun, O. (2007). Casualization and Casual Employment in Nigeria: Beyond Contract. Labour Law Review, 1, 14-34.

Atilola, B. (2014). Protecting the Rights of Casual Workers in Nigeria: Lessons from Ghana. Labour Law Review, 8, 1-11.

Bodibe, O. (2006). The Extent and Effects of Casualization in Southern Africa: Analysis of Lesotho, Mozambique, South Africa, Swaziland, Zambia and Zimbabwe (p. 55). Johannesburg: National Labour and Economic Institute.

Cheadle, H. (2006). Regulated Flexibility: Revisiting the LRA and Basic Conditions of Employment Act. Industrial Law Journal, 27, 663, 668.

Constitution of the Federal Republic of Nigeria 1999, as Amended, s 40.

Danesi, R. A. (2017). Labour Standards and the Flexible Workforce: Casualization of Labour under the Nigerian Labour Laws.

https://www.ilera-directory.org/15thworldcongress/files/papers/Track 4/Poster/CS1W 32 DANESI.pdf

Danesi, R. A. (2021). Labour Standards and the Flexible Workforce: Casualization of La-

${ }^{33}$ The Labour Act was decreed in 1974 by the Military Government of General Yakubu Gowon when nonstandard work arrangements were not very common in the country and subsequent amendments have not introduced the desired changes to bring it in line with international labour standards. 
bour under Nigerian Labour Laws. http://www.ilera-directory.org

Employees' Compensation Act 2010, s. 73.

Eyongndi, D. (2016). An Analysis of Casualization of Labour under Nigeria Law. Gravitas Review of Business and Property Law, 7, 102-116.

Fair Labour Association (2016). Labour Dispatch Workers in China. Issue Brief, March. https://www.fairlabour.org

Fapohunda, T. M. (2012). Employment Casualization and Degradation of Work in Nigeria. International Journal of Business and Social Science, 3, 257.

Fenwick, C., Kalula, E., \& Landau, I. (2007). Labour Law: A South African Perspective (p. 19). Geneva: International Institute for Labour Studies.

Fourie, E. S. (2008). Nonstandard Workers: The South African Context. International Law and Regulation by the European Union. Journal/Potchefstroomse Elektroniese Regsblad, 11, 109. https://doi.org/10.4314/pelj.v11i4.42242

ILO (1993). Resolution Concerning International Classification of Status in Employment. The International Conference of Labour Statisticians, January 1993, Paragraph 14(e). http://www.stats.oecd.org/glossary/detail.asp?ID=293

ILO (2003). The Scope of the Employment Relationship. In International Labour Conference, 91st Session, Report V(p. 37). Geneva: ILC.

ILO (2014). G Liu, Sector Working Paper No. 293: Private Employment Agencies and Labour Dispatch in China (pp. 16-19).

ILO (2016). Nonstandard Employment around the World: Understanding Challenges, Shaping Prospects (pp. 20-32).

Kalejaiye, P. O. (2014). The Rise of Casual Workers in Nigeria: Who Loses, Who Benefits? African Research Review, 8, 32. https://doi.org/10.4314/afrrev.v8i1.12

Labour Act 2004, s. 9(6)(a).

Labour Act No. 651 of 2003, s. 175.

Labour Act. Cap L1, Laws of the Federation of Nigeria, 2004.

May, R. et al. (2012). The Rise and Rise of Casual Work in Australia-Who Loses (pp. 102-103)? Sydney University, Seminar Paper 1; CB Okoro, Law of Employment in Nigeria (Concept Publications 2013).

Okafor, E.E. (2007). Globalization, Casualization and Capitalist Business Ethics: A Critical Overview of Situation in the Oil and Gas Sector in Nigeria. Journal of Social Sciences, 15, 169-179. https://doi.org/10.1080/09718923.2007.11892579

Otuturu, G. G. (2009). Freedom of Association and Trade Union Membership in Nigeria. Labour Law Review, 3, 63-64.

Palmer-Brown, J. (2017). Casualization of the Workforce: The Good, the Bad... and the Uncertain.

http://www.greatwesternpages.com.au/gwp--online--journal/2014/08/02/casualisationof-the-workforce-thegood-the-bad\%E2\%80\%A6-and-the-uncertain

Patovilki Industrial Planners Ltd v National Union of Hotels and Personal Services Workers (1978-2006) DJNIC 288-289.

PENGASSAN v Mobil Producing Nigeria Unlimited (2013) 32 NNLR (Pt. 92) 243.

Rasak, B. (2011). Casualization and Labour Utilization in Nigeria. International Labour Review, 65, 1-35. https://www.ilo.org/global/lang--en/index.htm

Sydney University, Seminar Paper 2012, 1.

The Minister of Labour, Employment and Productivity on 25th May 2011 Pursuant to 
Section 88(1) of the Labour Act 2004.

The Trade Unions Act, Cap T14, Laws of the Federation of Nigeria, 2004.

Worugji, I. N. E. (2013). Work Injuries Compensation under the Employee's Compensation Act in Nigeria: What Is Next? Journal of Law, Policy and Globalization, 10, 30, 32.

$\mathrm{Xu}, \mathrm{F}$. (2012). The Emergence of Temporary Staffing Agencies in China. Comparative Labor Law and Policy Journal, 30, 431-462. 